\title{
UNCONDITIONAL INCOME FOR LONG-TERM UNEMPLOYED PEOPLE AS SOLUTION IN GERMANY
}

\author{
Thomas Kronberger ${ }^{1}$
}

DOI: https://doi.org/10.31410/ERAZ.S.P.2019.129

\begin{abstract}
The classical Game Theory reflects the payoff of decision-makers. The conventional model has been expanded to a 3D Expanded Game Theory (EGT), including the consequences for the stakeholders. This model has the holistic benefits similar to the stakeholder model, but also allows forecasts like the classical Game Theory. This paper will discuss EGT.

This model is to be applied in the German labour market, where we have two decision-makers, an "unemployed person" and an "employee at job centre", as well as the stakeholder, "the state", who can influence both decision-makers in different ways. Germany has almost full employment on one hand and a hard core of long-term unemployed people on the other. Including these people in the labour market is very expensive and inefficient. This study will show how an unconditional income can be a possible solution for this specific group under the current German circumstances.
\end{abstract}

Keywords: Expanded Game Theory, Labour Market, Stakeholder, Decision Making.

\section{INTRODUCTION}

In Germany, we have the following framework:

- There is currently almost a full employment scenario,

- The long-term unemployed people are building relative constant groups,

- The cost of administrating long-term unemployed people and finding them jobs is high,

- The levels of stress and frustration of the employees at the job-centers are high,

- The levels of stress and frustration of the unemployed people are high.

The above are the reasons why the marginal benefit of job-searching efforts for long-term unemployed people is rather low. It will be shown, that under such conditions, an unconditional income can be a possible solution for all involved parties, as it reduces costs and increases the satisfaction of unemployed people as well as the employees at job centres.

For analysing the situation, it is necessary to take into account the theoretical background of Expanded Game Theory (EGT) and the economic condition in Germany. Having these two, EGT can be applied to find whether unconditional income is a possible solution for long-time unemployed people in Germany.

This paper does not consider the cases of short-term unemployed people and is based on a society with (almost) full-employment. In a society with a higher unemployment rate, the situation can be completely different.

Faculty of Management, Comenius University, Odbojárov 10, 82005 Bratislava, Slovakia 


\section{CURRENT SITUATION ON GERMAN LABOUR MARKET}

In the beginning of 2010s, several authors claimed Germany is on its way to full employment. [1] [2] According to Eurostat, in February 2019, the unemployment rate in Germany dipped to $3.1 \%$, which is the second lowest rate in the EU. [3]

Germany has significant economic differences amongst its regions. The Bundesagentur für Arbeit (BA) used a different approach to define unemployment rates compared to Eurostat and exhibited an unemployment rate of 5.3\% for Germany and a range from 3.2\% in the two southern states Bayern and Baden-Württemberg up to 9.8\% in Bremen. [4, p. 16] An interpolation of the methods, employed by Eurostat probably leads to an unemployment rate that is significantly lesser than $2 \%$ in the two southern states.

A current rigid source [5] considers an unemployment rate of $2 \%$ as full employment for Germany. Before this, other authors have considered quite higher values as full employment (for example, Bert Rürup in 2008 considered 4\% [6] while Robert E. Hall et al. considered 4-5\% [7]). Based on all these definitions, the German labour market can be considered to have fully employed workers, at least in some regions.

Nevertheless, in February 2019, 756,000 persons (31.9\% of all unemployed people) were unemployed for more than 12 months. These people are considered as long-term unemployed. This rate has been seen to reduce within the last 12 months (by 101,000 persons, from 33.7\%), mostly because of reduction in conversion from short-time unemployment to long-time unemployment ("Der Rückgang der Langzeitarbeitslosigkeit ist vor allem das Resultat von weniger Übertritten aus Kurzzeitarbeitslosigkeit"). [4, p. 13] Interestingly, this reduction does not result of long-term unemployed people entering the regular labour market. Thus, proves that the efforts for pushing and pulling long-term unemployed people to the regular labour-market has no significant effect on long-term unemployment, even though the BA considers the reduction of long-term unemployment as one of their main tasks. ("Die Reduzierung von Langzeitarbeitslosigkeit ist eines der Schwerpunktthemen der Bundesagentur für Arbeit (BA)") [8] In the last ten years, long-term unemployment-rate has been seen to be much more stable than the general unemployment-rate. [9, p. 622] One reason for the constant high rate of long-term unemployment is the digitalisation and the lack of qualification of the member of this group. [10]

In 2014, the efforts of BA with its about 95,000 employees only led to 154,000 long-term jobs (for all unemployed people, not only the long-term unemployed ones). This represents a ratio of only 1.6 jobs found per employee of the BA. [11]

Even if extra effort is invested, the possible extra benefit will be marginal compared to the costs incurred.

\section{CURRENT GERMAN LABOUR POLITICS AND ITS CONSEQUENCES}

After working for at least 2 years, in the case of unemployment, a moderate economic compensation will be granted for a maximum period of 12 months (independent of assets). [12] Afterwards a basic compensation ("Hatz IV") will be given for needy people. The rate is 424 $€$ plus housing costs for a single person (families get more). [13] Unemployed people need to collaborate to enjoy the full aid. 


\subsection{Consequences for long-term unemployed people}

There is a minimal chance for long-term unemployed people to go back to the regular labour market. [14]

The current system of forcing unemployed people is based on "carrot and whip". For example, the local office of the BA can grant $5 €$ for every job application (up to $260 €$ per year) [15]. On the other hand, if the unemployed person does not show enough effort in job hunting, he may be penalised with punishments such as reduction in social aid or, in the worst case, obligation to pay back the money to the local agency of the BA.

The economic loss of the punishments can impair the families - especially innocent children of the unemployed people. Economic restriction has often hampered the health and social life of unemployed people. The health status of long-term unemployed people is significantly worse than that of the median population. [16] [17] [18] Long term unemployment can lead to the stigmatisation of the unemployed people and their families. [19]

Some families cannot even afford any excursion; illness is an important topic for them. [20]

If there are sanctions, they can harm the people and strengthen the mentioned negative effects. Sanctions have a positive influence on activating employment; however, they are in conflict with the guarantee of subsistence [21], for which the state is responsible. But: The positive effect of sanctions for long-term unemployed people is marginal.

\subsection{Consequences for employees of $\mathbf{B A}$}

Employees of the BA agencies face negative effects of the German labour politics as well. They are under stress, for example, when asked to hold sanction discussions. For such discussions, a special training is elaborated. [22]

Currently, the German system is pushing the employee of the BA and the unemployed person to find a job until the unemployed person finds a job or reaches the age of retirement. This leads to stress, even more if the employee of the BA sees that his customer is unable/unwilling to search for a job.

In 2017 a query revealed that the working atmosphere at the BA is "disastrous". Unfortunately, detailed results were only published in the intranet of the BA. [23]

Also, this study found no scientific texts on the consequences for the employees of the BA; however, many journalistic contributions are available in print media [24] and TV [25]. There are also numberless comments on sites where employees can review their companies, such as Glassdoor and Kununu [26] among other internet forums. [27]

One comment on Glassdoor by a former recruitment agent summarises the consequences of the current labour politics: "Zero motivation because of lack success, utopic targets and unattainable workload" ("Null Motivation wegen mangelnden erfolgserlebnissen, utopische Zielvorgaben und unerreichbares arbeitspensum” [sic]). [28] 


\subsection{Consequences for the society/government}

The mentioned reclaim of the BA from the unemployed people led to an absurd situation in 2018 where local agencies of the BA had to spend $60,000,000 €$ to retrieve $18,000,000 €$ (sum of small amounts of less than $50 €$ each). [29]

The government pays a lot of money for job recruitments with a very small benefit of only 1.6 long-term jobs per employee of the BA per year. These costs lead to an unsatisfied population that criticises the inefficient and expensive administration. Before drawing a solution to the problem, the model of Expanded Game Theory will be explained.

\section{EXPANDED GAME THEORY}

\section{AS THE THEORETICAL BASIS FOR ANALYSIS}

The classical dyadic Game Theory model of von Neumann and Morgenstern [30] shows in a table the payoffs of two decision-makers depending on the decisions of their own as well as the other:

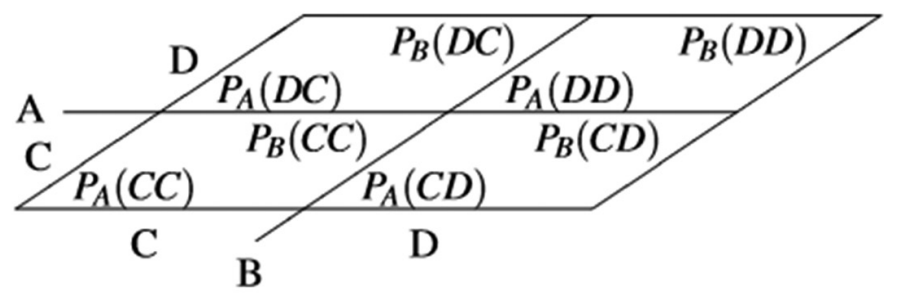

Figure 1: Classical Game Theory model (own visualisation)

This visualisation can be expanded to a 3D model [31] with the following three levels (in the case of one stakeholder, if there are more stakeholders, extra levels have to be added):

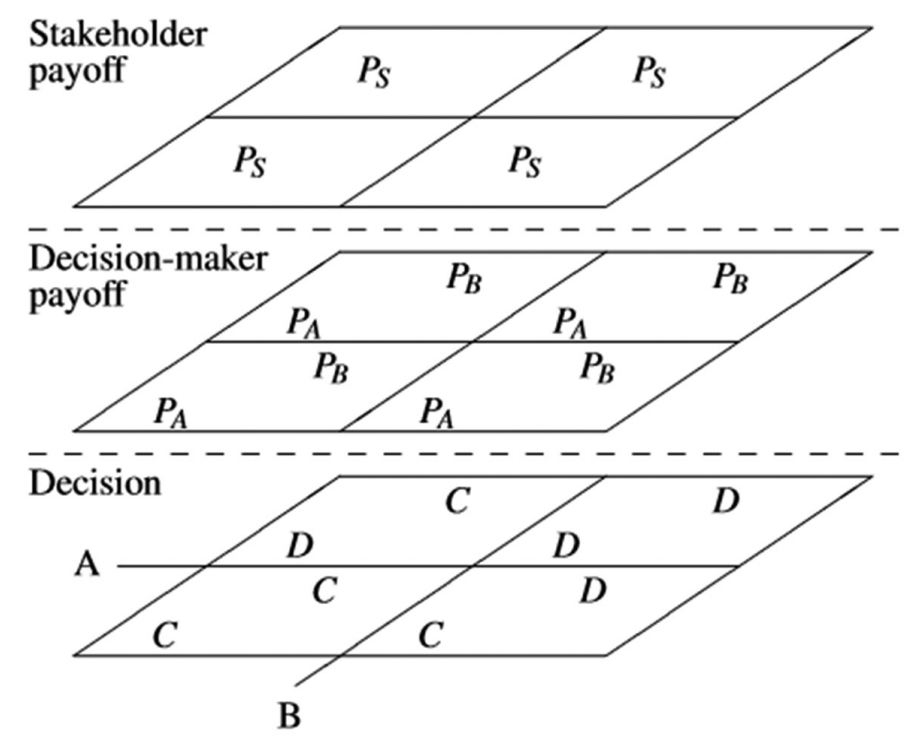

Figure 2: Expanded Game Theory with stakeholder (own elaboration)

Each level can be used by the decision-makers and the stakeholder for different purposes. The decision-makers will of course use the two lower levels of the model to find which output is the highest and how can they achieve it. The upper level shows the benefit of the stakeholder and can be used for getting a holistic view of the case. 
The stakeholder can consider each level corresponds to a different method that he can use to influence the decision-makers:

1. Stakeholder payoff level - Educating the decision makers: For the decision-maker to consider the stakeholder's suggestion, it is important that the stakeholder ensures the decision-makers acknowledge their existence as well as the consequences of ignorance.

2. Decision-maker payoff level - Adapting the framework so that the payoff for the involved parties change: If the payoff is adapted in a clever way, the decision-makers will have a lesser interest in taking decisions at the disadvantage of the stakeholders.

3. Decision level - Controlling the decision makers: If the decision-makers are controlled, the motivation for breaking rules is minimised.

\section{POSSIBLE SOLUTION: UNCONDTIONAL INCOME FOR LONG-TERM UNEMPLOYED PEOPLE}

Applying this model on the current case delivers the following:

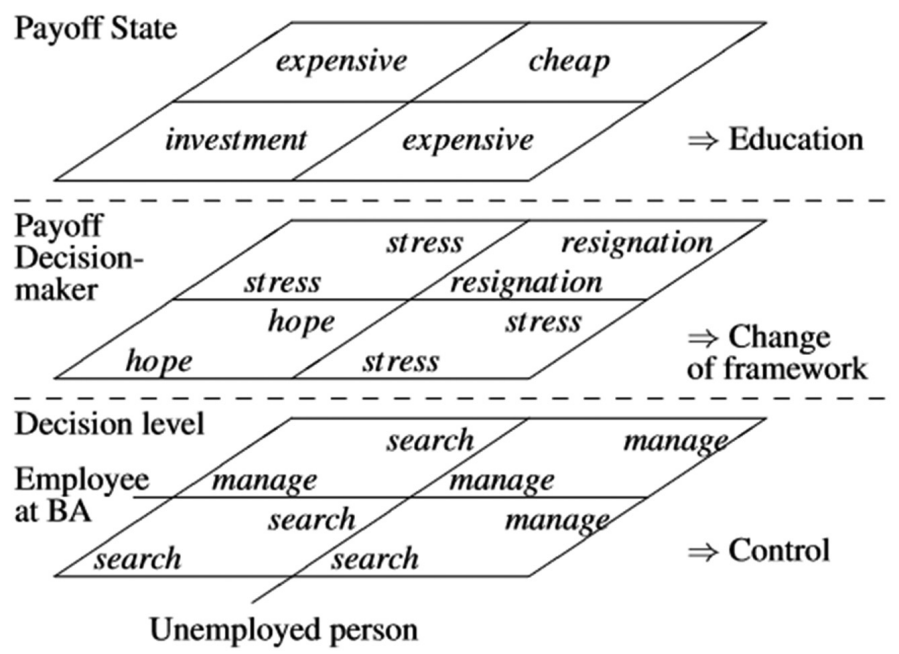

Figure 3: EGT applied on labour market (self-elaboration and see [11])

There are 4 possibilities:

1. search/search: The employee at the BA and the unemployed person are motivated in searching for a job. Both have hope, (can have) success and at least some satisfaction. The government is investing, i.e. paying the employee at the BA and providing income for the unemployed people. The possible profit for the government is mostly in the form of taxes levied, which the currently unemployed will pay once he gets a job.

2. search/manage: The employee at the BA is pushing and pulling the unemployed person to manage his situation. It is not important if the unemployed is unwilling or unable to search a job. Both the cases will result in stress for the two decision-makers and as expensive for the government; the latter because the government has to fund the work of the employee at the BA irrespective of whether the work is successful or not.

3. manage/search: The unemployed person is motivated to search for a job, and the employee at the BA is passive and only wants to administrate his customer. In this case, the employee at the BA gets his share for doing nothing, and the unemployed person stops believing in the BA. Thus, both are stressed, and again the government pays a lot of money for nothing.

4. manage/manage: Both, the employee at the BA and the unemployed person come to terms with the fact that they will not have success in finding a job and try to manage the 
situation. The unemployed person is not under pressure to deliver motivation letters and other proofs of job searching. The employee at the BA can use his time for cases that promise more success; this way, the government can save money.

This shows, that there are two possible solutions (Nash-equilibriums):

search/search: $\quad$ Forcing job searching

manage/manage: Unconditional income without obligation for job searching

The best solution is to avoid long-term unemployment. Of course, an early education is the best solution. [32] Another method (among others) involves increasing the mobility of unemployed people. [9, pp. 627-628] But, statistical data [9, p. 622] show for a large population of the longterm unemployed people, their situation is a way of no return.

The statistics of the BA (Table 1) reveals, that in the years 2013-2016, even with a decreasing unemployment rate (2.95 million $\rightarrow 2.69$ million), the group with an unemployment time for more than 5 years increased in number $(139,000 \rightarrow 156,000)$. The influence of the long-term unemployed people on the statistics has led to an increase in the average unemployment time (464 days $\rightarrow 495$ days) despite the number of unemployed people dipping. Interestingly, the time for finding a job is almost constant in these years (green highlighted values).

Table 1: Unemployment statistics from the BA (March 2019) [33]

\begin{tabular}{|c|c|c|c|c|c|c|c|c|c|c|c|}
\hline \multirow{4}{*}{ Time } & \multirow{3}{*}{ unem ployed } & \multicolumn{8}{|c|}{ of these } & \multirow{3}{*}{$\begin{array}{c}\text { average } \\
\text { time of } \\
\text { unem ploy- } \\
\text { ment }\end{array}$} & \multirow{3}{*}{$\begin{array}{c}\text { average } \\
\text { time for } \\
\text { finding a job }\end{array}$} \\
\hline & & \multirow{2}{*}{$\begin{array}{l}\text { not long- } \\
\text { temm }\end{array}$} & \multirow{2}{*}{$\begin{array}{l}\text { of these } \\
10-12 \\
\text { months } \\
\end{array}$} & \multirow[b]{2}{*}{ long-tem } & \multicolumn{5}{|c|}{ of these } & & \\
\hline & & & & & $1-2$ years & 2.3 years & $3-4$ years & $4-5$ years & $\begin{array}{c}5 \text { or more } \\
\text { years }\end{array}$ & & \\
\hline & 1 & 2 & 3 & 4 & 5 & 6 & 7 & 8 & 9 & 10 & 11 \\
\hline \multicolumn{12}{|c|}{ Jahresdurchschnitt } \\
\hline 2008 & 3.258 .954 & 1.932 .414 & 143.033 & 1.326 .540 & 506.976 & 303.074 & 245.372 & 91.779 & 176.140 & 525 & 295 \\
\hline 2009 & 3.414 .992 & 2.276 .860 & 159.718 & 1.138 .132 & 486.801 & 217.256 & 150.308 & 134.699 & 147.147 & 452 & 258 \\
\hline 2010 & 3.238 .965 & 2.098 .596 & 167.672 & 1.140 .368 & 566.522 & 206.892 & 114.546 & 84.894 & 166.953 & 451 & 265 \\
\hline 2011 & 2.976 .488 & 1.908 .358 & 149.868 & 1.068 .130 & 512.228 & 224.986 & 108.173 & 65.520 & 153.263 & 459 & 260 \\
\hline 2012 & 2.897 .126 & 1.850 .491 & 141.138 & 1.046 .635 & 499.733 & 210.164 & 117.655 & 62.638 & 138.215 & 458 & 260 \\
\hline 2013 & 2.950 .338 & 1.880 .616 & 143.246 & 1.069 .721 & 505.445 & 228.689 & 120.401 & 73.716 & 139.367 & 464 & 262 \\
\hline 2014 & 2.898 .388 & 1.821 .637 & 139.594 & 1.076 .752 & 490.405 & 229.540 & 132.864 & 76.174 & 146.918 & 481 & 267 \\
\hline 2015 & 2.794 .664 & 1.755 .383 & 133.485 & 1.039 .281 & 458.704 & 214.973 & 130.146 & 82.513 & 151.657 & 492 & 266 \\
\hline 2016 & 2.690 .975 & 1.697 .902 & 122.957 & 993.073 & 436.908 & 198.929 & 119.853 & 79.919 & 156.282 & 495 & 268 \\
\hline 2017 & 2.532 .837 & 1.632 .093 & 114.879 & 900.745 & 388.424 & 181.618 & 105.849 & 70.301 & 153.950 & 490 & 262 \\
\hline 2018 & 2.340 .082 & 1.526 .674 & 104.076 & 813.409 & 352.459 & 155.061 & 96.184 & 61.540 & 145.773 & 488 & 259 \\
\hline
\end{tabular}

For the long-term unemployed people, there needs to be a solution. For them, the question is not "How can long-term unemployment be reduced?" [34] but rather "How is a decent life possible with long-term unemployment?" The affected persons need to participate in their social life and exclusion needs to be avoided. On the other hand, a shift from the working part to the non-working part of the population needs to be avoided, and the working part of the society should not feel overburdened.

Stopping job-searching can mean one of the following four basic things:

\subsection{Stop supporting the unemployed people}

This solution is against the German constitution [35]. Greece is the only country in the EU where economic support is not perceived after a certain period of time [36]. Belarus went even a step further than Greece. Belarus does not only stop supporting the unemployed people, it even asked 
money from them. Belarus' leader Alexander Lukashenko installed a "parasite tax" for the unemployed. Who has no job, has to pay, because most likely he works illegal? Due to the protests from the unsatisfied population, he cancelled the "parasite tax" after a short period of time in 2018. [37]

\subsection{Providing unconditional income only in regions with (high) unemployment}

In the first instance, this appears as a good idea: give money to the people of those places that have no jobs. However, in Germany regions with a high unemployment rate are poorer than the rest of the country. [38] Therefore, an unconditional income will only burden cities with a poor economic status and, as its negative side effect, influence the unemployed people from richer regions to move to these places to gain easy money. Apart from economic consequences with wrong incentives, the segmentation of the country leads to political consequences, which are explained in the next sub-chapter:

\subsection{Providing unconditional income only in regions with full employment.}

A fragmentation of the country in two sections, areas with and without unconditional income, can be compared to the regional differentiated minimum wage. Such has been seen to be practiced in some countries such as Brazil (between $998 \mathrm{R} \$$ (about 226€) and 1335.20 R\$ (about $303 €)$ ) [39]. Economic differences perceived here are much bigger than in Germany. The Brazilian South East can be considered a first world country with an equivalent life cost level. Poorer regions comprise more than 8000 schools without electricity. In some schools, pupils even have to bring their own water in buckets. [40] In Germany, the differences are not that big. Nevertheless, a regional basic salary was calculated [41] but is not realised due methodical difficulties. [42] The same difficulties exist in dividing the country in two sections: one with unconditional income and the other one without it.

Germany was divided for more than 28 years, the effects of which have not been overcome up to now. Many people are still of the belief that Germany is divided. This may be another reason why the government is trying to avoid regional differentiations of minimum wages and social welfare.

Nevertheless, as thought-experiment, it will be interesting because unemployed people living in a region with a high unemployment rate will have two reasons to move to a region with a low unemployment rate: more jobs and unconditional income.

\subsection{Providing unconditional income throughout Germany}

Therefore, the only feasible option left is to provide unconditional income throughout Germany. This will result in the following benefits for all involved parties:

Benefit for the long-term unemployed person (and his family):

- As there are no sanctions, the unemployed will have planning reliability about their money. This may also improve their health and reduce their probability to commit a crime, especially robbery (because they are less needy) and vandalism (less frustration).

- This may also result in greater satisfaction, as there will be no need to prove for job-searching activities. Nevertheless, this way, the unemployed can decide whether they want to search for a job or not. The possibility of job-searching and the support of the BA is still in existence. 
Benefit for employee of the BA:

- Employees are only in contact with long-term unemployed people willing/able to search for a job and short-term unemployed people (who have a high chance for finding a job). Therefore, these two groups of unemployed have a higher motivation and/or a higher success rate compared to the hopeless cases.

Benefit for the society:

- Since the motivation of the employee of the BA will be higher than before, they will reflect their happiness in their family, which is a part of the society.

- As mentioned before, this may also reduce health costs and crime rates.

- Less unmotivated people will write motivation letters for jobs they are not well-suited for; this will in turn decrease the costs incurred by the companies. All these aspects will have a positive effect on the society. There will be lesser stress and the society in general will be happier. This happiness has no monetary in western countries; In Bhutan, the "Gross National Happiness" even has a constitutional status. [43]

\section{CONCLUSION \& OUTLOOK}

When the author first learnt about unconditional income, he was against the policy of supporting unemployed people without demanding anything from them. After researching on this topic and understanding the situation of the involved parties, his opinion changed at least for the longterm unemployed people in Germany.

He now believes that it is the best for all three involved parties (unemployed people, employees of the BA and society) to stop forcing on job searching after a certain time. Finding the correct moment for "resigning searching" is very hard and can be compared with chess computers. Douglas R. Hofstadter in 1979 wrote the following in his famous book "Gödel, Escher, Bach" about a chess program, "In a computer chess tournament not long ago in Canada, one program the weakest of all the competing ones - had the unusual feature of quitting long before the game was over. It was not a very good chess player, but it at least had the redeeming quality of being able to spot a hopeless position, and to resign then and there, instead of waiting for the other program to go through boring ritual of checkmating. Although it lost every game it played, it did it in style." [44] As forum contributions show, still today chess programs have the "problem" that they do not know when to resign. [45]

Seeing that computers cannot find the right moment to resign in a chess game, one can realise that it is even harder for them to find the right moment to resign in job searching, where many aspects have to be regarded. One of these aspects is considering the possibility that the probability of finding a job decreases over time. The first indicator of this can be seen from the statistics of the BA (see Table 1). Acceptance of population, economic situation and change in unemployment rates are a few of the many other aspects that need to be regarded for finding the right moment to switch to unconditional income. How can one find the best moment, can be covered in another paper. Other interesting further research-topics are the long-term effects and the social impact of an unconditional income.

The author thinks, that the amount of the unconditional income is more a political decision than a scientific. 


\section{REFERENCES}

[1] T. Straubhaar, „Wege zur Vollbeschäftigung,“ Aus Politik und Zeitgeschichte, pp. 3-7, Vol. $62(14 / 15), 2012$.

[2] K.-H. Paqué, „Deutschlands Weg zur Vollbeschäftigung,“ Orientierungen zur Wirtschafts und Gesellschaftspolitik, pp. 28-35, Issue 1362013.

[3] Eurostat, „Unemployment statistics““ Eurostat, March 2019. [Online]. Available: https:// ec.europa.eu/eurostat/statistics-explained/index.php?title=Unemployment_statistics. [Zugriff am 0205 2019].

[4] Bundesagentur für Arbeit, „Monatsbericht zum Arbeits- und Ausbildungsmarkt,“ Bundesagentur für Arbeit, Nürnberg, 2019.

[5] Bundeszentrale für politische Bildung, „www.bpb.de,“ Bundeszentrale für politische Bildung, 2016. [Online]. Available: http://www.bpb.de/nachschlagen/lexika/lexikon-derwirtschaft/21068/vollbeschaeftigung. [Zugriff am 0502 2019].

[6] Welt.de, „Ab wann man von Vollbeschäftigung spricht,“ welt.de, 0105 2008. [Online]. Available: https://www.welt.de/wirtschaft/article1955723/Ab-wann-man-von-Vollbeschaeftigung-spricht.html. [Zugriff am 0205 2019].

[7] R. E. Hall, R. A. Gordon und C. Holt, „Why Is Unemployment Rate So High at Full Employment?“" Brookings Papers on Economic Activity, pp. 369-410, No. 31970.

[8] Bundesagentur für Arbeit, „Langzeitarbeitslosigkeit,“ Bundesagentur für Arbeit, [Online]. Available: https://statistik.arbeitsagentur.de/Navigation/Statistik/Statistik-nach-Themen/ Langzeitarbeitslosigkeit/Langzeitarbeitslosigkeit-Nav.html. [Zugriff am 0205 2019].

[9] U. Walwei, „Abbau der Langeitarbeitslosigkeit: Der Weg ist steinig und schwer,“ Wirtschaftsdienst, pp. 621-628, 20092017.

[10] B. Klauß, „Wie Richard David Precht den Sozialstaat retten will,“ 2605 2019. [Online]. Available: https://www.rnz.de/wirtschaft/wirtschaft-regional_artikel,-bedingungsloses-grundeinkommen-wie-richard-david-precht-den-sozialstaat-retten-will-_arid,442421. html. [Zugriff am 2705 2019].

[11] T. Kronberger und L. Papakonstantinidis, „,,The Win-Win-Win Papakonstantinidis Model": Bargaining Possibilities When there are Three Involved Parties on a Labour Market and two of them are Active Decision-Makers," International Journal of Innovation and Economic Development, pp. 68-98, Volume 4022019.

[12] Lohnsteuer kompakt, „Wie lange wird Arbeitslosengeld gezahlt?,“ Lohnsteuer kompakt, [Online]. Available: https://www.lohnsteuer-kompakt.de/fag/0/677/wie_lange_wird_arbeitslosengeld_gezahlt. [Zugriff am 0502 2019].

[13] Hartz IV, „Hartz IV Erhöhung kommt Mehr Geld ab 2019,“ Hartziv.org, 12092018. [Online]. Available: https://www.hartziv.org/news/20180912-hartz-iv-erhoehung-kommtmehr-geld-ab-2019.html. [Zugriff am 0205 2019].

[14] A. Brück-Klingberg und J. Althoff, Langzeitarbeitslosigkeit in Niedersachsen - wenig Bewegung und hohes Niveau: Entwicklung, Struktur und Abgänge in Beschäftigung, Nürnberg: IAB-Regional Niedersachsen-Bremen, 2018.

[15] besserbewerben.de, „bewerbungstipps/bewerbungskosten-erstattung-vom-arbeitsamt-die-5-euro-pauschale,“ [Online]. Available: https://www.besserbewerben.de/bewerbungstipps/bewerbungskosten-erstattung-vom-arbeitsamt-die-5-euro-pauschale. [Zugriff am 0205 2019].

[16] S. Kreuzfeld, M. Weippert, M. Kumar, A. Rieger und R. Stoll, „Arbeitsmarktintegratives Setting mit Gesundheitsberatung unterstützt gesundheitsförderlichen Lebensstil bei Langzeiterwerbslosen,“ KNP/BMBF-Förderschwerpunkt Präventionsforschung - Wirksamkeit Erwachsene, p. 77 (Suppl. 1): S101-S102, 2015. 
[17] H. Limm, H. Gündel, M. Heinmüller, K. Liel, K. Seeger und P. Angerer, „Gesundheitsförderung für Menschen in Langzeitarbeitslosigkeit,“ KNP/BMBF-Förderschwerpunkt Präventionsforschung - Wirksamkeit Erwachsene, p. 77 (Suppl. 1): S99-S100, 2015.

[18] K. Liel, „Evaluation eines Gesundheitskompetenztrainings für Menschen in Langzeitarbeitslosigkeit,“ 2012. [Online]. Available: https://edoc.ub.uni-muenchen.de/14510/1/Liel Katrin.pdf. [Zugriff am 0205 2019].

[19] T. Gurr und M. Jungbauer-Gans, „Stigma consciousness among the unemployed and prejudices against them: development of two scales for the 7th wave of the panel study "Labour Market and Social Security (PASS)", Journal of Labour Market Research, pp. 335351, Volume 46 December 2013.

[20] C. Thiel und S. Götz, „Mehr als nur reden - Methodische Betrachtungen zu Interviews mit Familien,“ Sozialer Sinn, Heft 1 Band 192018.

[21] I. Kumpmann, „Im Fokus: Sanktionen gegen Hartz-IV-Empfänger: Zielgenaue Disziplinierung oder allgemeine Drohkulisse?,“ Wirtschaft im Wandel, pp. 236-239, 06 2009.

[22] R. Göckler, „Sanktionsgespräche in der Grundsicherung für Arbeitssuchende (SGB II) und ihre Anschlussfähigkeit zu Beratungsstandards,“ Sozialer Fortschritt, pp. 264-272, Heft 10-11 2010.

[23] dpa, „Bundesagentur für Arbeit: Befragung offenbart desaströses Betriebsklima,“ Handelsblatt.com, 2211 2017. [Online]. Available: https://www.handelsblatt.com/politik/deutschland/bundesagentur-fuer-arbeit-befragung-offenbart-desastroeses-betriebsklima/20620814. html?ticket=ST-892172-ZxsUfDxeopcGn3VE67kA-ap3. [Zugriff am 0205 2019].

[24] A. Gehrmann, „Egal, Hauptsache irgendein Job,“ spiegel.de, 2704 2017. [Online]. Available: https://www.spiegel.de/lebenundlernen/job/arbeitsagentur-7-tage-als-sachbearbeiterin-a-1144744.html. [Zugriff am 0205 2019].

[25] NDR, Regisseur, Jobs, soziale Sicherheit, Hilfe? Der Alltag bei der Agentur für Arbeit - 7 Tage. [Film]. Deutschland: NDR, 2017.

[26] kununu.com, „Bundesagentur für Arbeit als Arbeitgeber,“ kununu.com, [Online]. Available: https://www.kununu.com/de/bundesagentur-fuer-arbeit/kommentare. [Zugriff am 02 05 2019].

[27] wiwi-treff,de, „Arbeitsvermittler Bundeagentur für Arbeit - und danach?,“ wiwi-treff.de, [Online]. Available: https://www.wiwi-treff.de/Berufseinstieg-Wo-and-Wie/AA/Arbeitsvermittler-Bundesagentur-fuer-Arbeit-und-danach/Diskussion-19429. [Zugriff am 0205 2019].

[28] Glassdoor, „Arbeitgeberbewertung: Bundesagentur für Arbeit,“ glassdoor.com, [Online]. Available: https://www.glassdoor.de/Bewertungen/Bundesagentur-f\%C3\%BCr-Arbeit-Arbeitsvermittler-Bewertungen-EI_IE930843.0,24_KO25,42.htm. [Zugriff am 0205 2019].

[29] dpa, „Jobcenter zahlen 60 Millionen Euro, um 18 Millionen einzunehmen,“ faz. net, 2702 2019. [Online]. Available: https://www.faz.net/aktuell/wirtschaft/rueckforderung-von-kleinbetraegen-kostet-jobcenter-millionen-16062458.html. [Zugriff am 02 05 2019].

[30] J. v. Neumann und O. Morgenstern, Theory of games and economic behavior, Princeton: Princeton University Press, 1944.

[31] T. Kronberger, „Unethical cooperation and its consequences for stakeholders: Insights from Game Theory, “ Brno, 2017.

[32] F. Bauer und G. Sieglen, „Individuell verfestigte Langzeitarbeitslosigkeit,“ Arbeit Zeitschrift für Arbeitsforschung, Arbeitsgestaltung und Arbeitspolitik, pp. 87-107, 1405 2018. 
[33] Bundeasagentur für Arbeit, „Statistikdaten Langzeitarbeitslosigkeit,“ 03 2019. [Online]. Available: https://statistik.arbeitsagentur.de/Statistikdaten/Detail/201903/langzeitarbeitslosigkeit/ langzeitarbeitslosigkeit/langzeitarbeitslosigkeit-dlk-0-201903-xlsm.xlsm. [Zugriff am 0205 2019].

[34] N. Blüm, R. Dreßler, K. Murmann und E. Breit, „Wie kann die Langzeitarbeitslosigkeit abgebaut werden?““ Wirtschaftsdienst, pp. 323-331, Vol.69 (7) 1989.

[35] K. F. Gräditz, „Das verfassungsrechtliche Existenzminimum im „Hartz IV“-Urteil des Bundesverfassungsgericht,“ $B R J$, pp. 4-11, 12010.

[36] Handelsblatt, „Hartz IV auf Griechisch,“ handelsblatt.com, 2601 2015. [Online]. Available: https://www.handelsblatt.com/politik/international/grundsicherung-in-europa-undden-usa-hartz-iv-auf-griechisch/10968098-all.html. [Zugriff am 0903 2019].

[37] Radio Free Europe, „Lukashenka Cancels 'Parasite Tax' Unemployed in Belarus,“ Radio Free Europe, 2601 2018. [Online]. Available: https://www.rferl.org/a/belarus-lukashenka-cancels-parasite-tax/28999724.html. [Zugriff am 0205 2019].

[38] F. Diekmann, F. Kalinowski und C. Kurt, „Armes Deutschland, reiches Deutschland,“ spiegel.de, 2103 2016. [Online]. Available: https:/www.spiegel.de/wirtschaft/soziales/ungleichheit-wo-deutschland-stark-und-schwach-ist-in-10-karten-a-1083053.html. [Zugriff am 0605 2019].

[39] iDoméstica, „Salário Mínimo de Empregada Doméstica em 2019,“ idomestica.com, [Online]. Available: https://www.idomestica.com/tabelas/salario-empregada-domestica . [Zugriff am 0205 2019].

[40] Bom Dia Brasil, „Brasil tem oito mil escolas sem energia elétrica e até sem água,“ globo. com, 3004 2014. [Online]. Available: http://g1.globo.com/bom-dia-brasil/noticia/2014/04/ brasil-tem-oito-mil-escolas-sem-energia-eletrica-e-ate-sem-agua.html. [Zugriff am 0205 2019].

[41] A. Herzog-Stein, M. Lübker, T. Pusch, S. T. und A. Watt, „Der Mindestlohn: Bisherige Auswirkungen und zukünftige Anpassungen,“Hans-Böckler-Stiftung, Düsseldorf, 2018.

[42] A. Endres, „Interview with Stefan Sell: "Es gäbe gute Gründe für eine Erhöhung”,“ handelsblatt.com, 2604 2018. [Online]. Available: https:/www.zeit.de/wirtschaft/2018-04/ mindestlohn-erhoehung-hans-boeckler-stiftung-arbeitsmarkt-stefan-sell/komplettansicht. [Zugriff am 0205 2019].

[43] Lexikon der Nachhaltigkeit, „Bruttonationalglück in Bhutan,“ nachhaltigkeit.info, 1211 2015. [Online]. Available: https://www.nachhaltigkeit.info/artikel/bruttoinlandsglueck_ in_buthan_1869.htm. [Zugriff am 0205 2019].

[44] D. R. Hoftstadter, Gödel Escher Bach, New York: Basic Books, 1979.

[45] Quora, „Why do computers never resign in chess when they are going to lose for sure?“ Quora.com, [Online]. Available: https://www.quora.com/Why-do-computers-never-resign-in-chess-when-they-are-going-to-lose-for-sure. [Zugriff am 0205 2019]. 